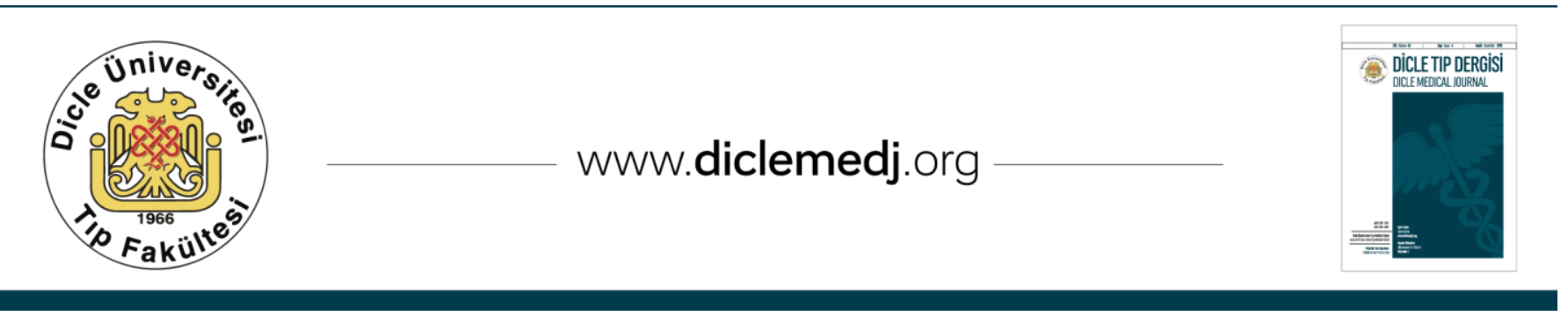

Case Report /Olgu Sunumu

\title{
A Stuttering Case Getting Well During Bipolar Disorder Manic Episode
}

\author{
Betül Uyar Ekmen1 \\ 1 Selahaddin Eyyubi Devlet Hastanesi Ruh Sağlığı Ve Hastalıkları Diyarbakir, Türkiye ORCID: 0000-0002-6428-1097
}

Received: 11.09.2018; Revised: 24.09.2018; Accepted: 04.10.2018

\begin{abstract}
Bipolar disorder; is a chronic disease with recurrent mania, hypomania and depression episodes. The cyclical progress of the disorder, with recovery and exacerbations, affects the individual physically and mentally and disturbs the patient's professional and social harmony. Stuttering is defined as the disorder in which the individual's speech is not following his / her age due to fluency or timing. However, the etiology of shuttering has not yet understood. It is thought that, during the conversation, the thought of the negative reactions that the patient might encounter, affects the fluency of the speech.

Researches on stuttering in bipolar disorder are limited.

In this article, we discussed a case who has stuttering since childhood and whose stuttering got well during bipolar disorder manic episodes. It was observed that the patient's stuttering complaint was resumed when the patient had reached the euthymic state by the treatment.
\end{abstract}

Keywords: bipoar disorder, stuttering, manic episode 


\section{Bipolar Bozukluk Manik Hecme Sırasında Düzelen Bir Kekemelik Olgusu}

\section{Öz}

Bipolar bozukluk; yineleyen mani, hipomani ve depresyon dönemleri ile karakterize süreğen bir hastalıktır. Hastalık, atak dönemleri ve atakların arasında remisyon dönemleri ile seyreder. Bipolar bozukluk, kişiyi fiziksel ve ruhsal olarak olumsuz etkileyerek kişinin sosyal adaptasyonuna zarar vermektedir.

Kekemelik, bireyin konuşmasının akıcılık ve zamanlamasının yaşına uygun olmayan şekilde bozulmasıdır. Kekemeliğin etyolojisi tam olarak açıklanamamaktadır. Ancak konuşma esnasında, kişinin dinleyicilerden kaynaklanabileceğini düşündüğü olumsuz tepkilerin konuşmasının başlamasını ve akıcllı̆̆ını engellediği düşünülmektedir. Bipolar bozuklukta kekemelik araștırmaları kısıtlı sayıdadır.

Bu yazıda çocukluktan beri kekemeliği olan ve bipolar bozukluk manik hecme sırasında kekemeliği düzelen bir olgudan bahsettik. Tedavi ile ötimik duruma geldikten sonra hastanın kekemelik şikayetinin tekrar başladığı gözlenmiştir.

Anahtar kelimeler: Bipolar bozukluk, kekemelik, manik dönem.

\section{INTRODUCTION}

Bipolar disorder (BD) is a chronic disease that includes recurring mania, hypomania, and depression periods. In manic episode appear symptoms such as feeling overly happy, decreasing sleeping time, increasing speech rate and amount, impulsivity, increasing in selfesteem, tendency to risky activities ${ }^{1}$. In the past, lifetime frequency was assumed to be $1 \%$, but in recent years it is estimated to be $5 \%$ when BD has been considered as a spectrum. The cyclical course of the disorder, with recovery and exacerbations, affects the individual physically and mentally and disturbs the patient's professional and social harmony2.

Stuttering is defined as the disorder in which the individual's speech is not by his / her age due to fluency or timing ${ }^{3}$. The stuttering frequency of $1 \%$ in the general population is around $2-4 \%$ among children ${ }^{4}$. The etiology of stuttering is defined within the framework of the factors that cause, raise and sustain the problem. The mechanisms underlying the inability to start talking are not yet clarified. It is thought that, during the conversation, negative reactions that the patient thinks she might face, affects the fluency of the speech ${ }^{5}$.
The relationship between $\mathrm{BD}$ and stuttering has been rarely researched, and studies are generally case reports. These case reports

emphasized emerging stuttering by the drugs used in BD treatment.

\section{CASE}

The patient is 21 years old, female, single and living in a dorm in a different city from her family. She is making her education at a university, in her second-grade, and has good scores. She and her family have no previous psychiatric disorder history, and she also has no addiction to any substances.

Two weeks ago, she had several disturbing symptoms including; feeling extensively happy, hypermobility, not being able to concentrate, the pleasure to help others, increasing in speech, fast and pressured speech, and a significant reduction in her sleeping times.

By the mental state examination we made, her mood was euphoric, and affect was congruent to her mood. Amount of speech had increased, her speech was fast and pressure. She seemed extensively energetic, and her psychomotor activity has increased although her sleeping time was reduced to two hours a day. Her associations were distributed but reaching to aim. She had new plans for the life and her 
future. She had no insight and stated that she came to the hospital with the pressure of her parents. She claimed that her aim in coming to the hospital is giving happiness to all people around. She was willing to visit and deliver presents to all patients in the hospital. There were no psychotic symptoms and no stuttering. The patient was talking fluent and serial.

We learned from her parents that she had stuttering since her childhood. Mainly she had problems starting a word or sentence. Her complaint was increasing by the stress. Stuttering was affecting her social relations and especially in crowded places she was hesitating to talk. She has the concern of getting mocked if she stutters during the conversation. In the friendly and safe areas, she was having less stuttering.

In the laboratory tests, there was no anomaly. (regular biochemistry, hemogram, cyanocobalamin (B12 vitamin), folic acid \& thyroid function).

With these investigations, we diagnosed the patient as the BD manic episode with no psychotic features. We started treatment of $1000 \mathrm{mg} /$ day valproic acid and $200 \mathrm{mg} /$ day quetiapine. In a month, her manic symptoms gradually reduced and the patient came to the euthymic state.

In the mental state examination when the patient was in a euthymic state, it is seen that she was stuttering particularly while starting a word or sentence. Sometimes, she was having a deep trouble finishing a word. It was observed that her stuttering continued in the following meetings.

\section{DISCUSSION}

In this case, we discussed the patient's stuttering got well during BD manic episode. Unlike our case in the literature, two cases reported that stuttering appeared during the catatonia in BD manic episode 6 . Furthermore, a study indicated that the stuttering was exaggerated with lithium treatment in a patient with BD ${ }^{7}$. Also, various studies reported triggered stuttering with olanzapine, clozapine and risperidone treatment ${ }^{8-10}$.

However, the etiology of stuttering has not yet understood. It is thought that, during the conversation, negative reactions that the patient thinks she might face, affects the fluency of the speech ${ }^{5}$. We concluded that the stuttering might be disappeared due to the changes in the manic episodes of $\mathrm{BD}$, such as euphoria, the increment in self-respect, increasing amount and pressure of speech.

Declaration of Conflicting Interests: The authors declare that they have no conflict of interest.

Financial Disclosure: No financial support was received.

\section{REFERENCES}

1. Baldessarini RJ, Pérez J, Salvatore P, et all. History of bipolar manic-depressive disorder. Chapt 1. In Yildiz A, Nemeroff C, Ruiz P, editors. The bipolar book: history, neurobiology, and treatment. New York: Oxford University Press; 2015. pp 3-20.

2. Sierra P, Livianos L, Rojo L. Quality of life for patients with bipolar disorder: Relationship with clinical and demographic variables. Bipolar Disord. 2005; 7: 159. 65.

3. American Psychiatric Association. Diagnostic and statistical manual of mental disorders, 5th edition. Washington, DC: American Psychiatric Association; 2013.

4. Yairi E, Seery CH. Stuttering: Foundations and clinical applications. Boston: Pearson, 2015.

5. Guntupalli VK, Everhart DE, Kalinowski J, et all. Emotional and physiological responses of fluent listeners while watching the speech of adults who stutter. Int J Lang Comm Dis. 2007; 42: 113-29.

6. Joseph AB. Transient stuttering in catatonic bipolar patients. Behav Neurolog 1991; 4: 265-9.

7. Gulack BC, Puri NV, Kim WJ. Stutter exacerbated by lithium in a pediatric patient with bipolar disorder. Ann Pharmacother. 2011; 45: e57.

8. Yadav DS. Risperidone induced stuttering. General Hospital Psychiatry, 2010; 32: 559-e9. 
9. Grover S, Verma AK, Nebhinani N. Clozapine-induced stuttering: a case report and analysis of similar case reports in the literature. General hospital psychiatry, 2012; 34: 703-e1.
10. Lasić D, Žuljan Cvitanović M, Krnić S, et all. Olanzapine induced stuttering: a case report. Psychiatria Danubina, 2016; 28: 299-300. 